\title{
Upping the Ante: Collective Litigation in Latin America
}

Ángel Oquendo

University of Connecticut School of Law

Follow this and additional works at: https://opencommons.uconn.edu/law_papers

Part of the Civil Procedure Commons, Comparative and Foreign Law Commons, and the Law and Society Commons

\section{Recommended Citation}

Oquendo, Ángel, "Upping the Ante: Collective Litigation in Latin America" (2009). Faculty Articles and Papers. 228.

https://opencommons.uconn.edu/law_papers/228 


\section{HEINONLINE}

Citation: 47 Colum. J. Transnat'I L. 248 2008-2009

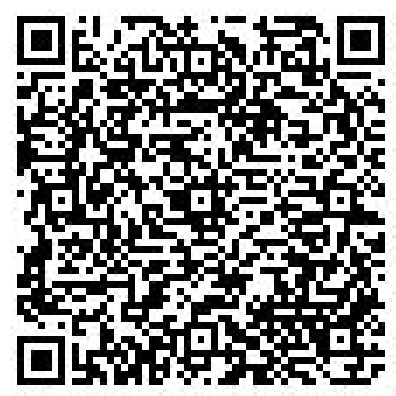

Content downloaded/printed from

HeinOnline (http://heinonline.org)

Tue Aug 16 13:02:17 2016

-- Your use of this HeinOnline PDF indicates your acceptance of HeinOnline's Terms and Conditions of the license agreement available at http://heinonline.org/HOL/License

-- The search text of this PDF is generated from uncorrected OCR text.

-- To obtain permission to use this article beyond the scope of your HeinOnline license, please use:

https://www.copyright.com/ccc/basicSearch.do?

\&operation $=$ go \&search Type $=0$

\&lastSearch $=$ simple\&all $=$ on\&titleOrStdNo $=0010-1931$ 


\title{
Articles
}

\section{Upping the Ante: Collective Litigation in Latin America}

\author{
ÁNGEL R. OQUENDO*
}

This work contends that Latin America has launched a true revolution on collective rights: moving beyond the paradigm of group entitlements, which concern a determinate - though potentially enormouscollectivity, to that of comprehensive entitlements, which generally pertain to society as a whole. Latin American jurisdictions have created innovative procedural mechanisms in this area: the collective writ of protection for the realization of group rights, the popular action for the civic vindication of comprehensive entitlements, and the public civil action for the official enforcement of both kinds of rights. The U.S. legal order has much to learn from a comparative reflection upon these developments. It could, accordingly, open up to the creation of a universally available citizen's suit, the institution of an autonomous state body with power to file complaints on behalf of communal and societal interests, the concession of standing to organizations (as well as individuals) to pursue class suits, and the introduction of a single, straightforward classification under Rule 23(b) of the Federal Rules of Civil Procedure. The article concludes by calling attention to the tension between

* Olimpiad S. Ioffe Professor of International and Comparative Law, University of Connecticut. Ph.D., M.A. (Philosophy), A.B. (Economics and Philosophy), Harvard University; J.D., Yale Law School. The author would like to thank Anne Dailey, Humberto Dalla, Julianne Lombardo, and Joseph Page for their extremely helpful comments on earlier drafts. 
Latin American efforts to implement trans-individual guaranties and the sporadic precariousness of the rule of law in the region. It argues that, beyond adopting new measures or punishing violators more severely, the countries affected must broadly enhance the legitimacy of legal norms by renewing their commitment to democracy, as well as to other ideals, such as the rule of law itself, personal freedom, and (above all) solidarity.

I. WARM-UP

II. Collective Litigation: CONCEPT AND COMPARATIVE CONTEXT 253

III. Collective Writs of Protection OR SECURITY ................ 262

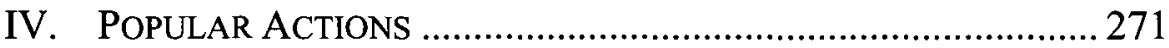

V. PUBLIC CIVIL ACTIONS....................................................... 277

VI. RESTRUCTURING U.S. REPRESENTATIVE LITIGATION .............. 284

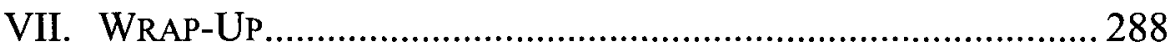

Nos cruzamos en noche de ventisca; en las mismas posadas estuvimos, ciegos dormidos y ciegos despiertos. - GABRIEla Mistral, Dos trascordados, LAGAR II (1991)

I. WARM-UP

Upon accepting the Nobel Prize for Literature in Stockholm, Gabriel García Márquez spoke these words: "América Latina no quiere ni tiene por qué ser un alfil sin albedrio, ni tiene nada de quimérico que sus designios de independencia y originalidad se conviertan en una aspiración occidental." 2 Indeed, Latin (or Iberian) ${ }^{3}$

1. Literally: "Our paths crossed on that blustery night; we lodged at the same inns, blindly asleep and awake."

2. Gabriel García Márquez, Recipient of 1982 Nobel Prize in Literature, Nobel Lecture: La soledad de América Latina (Dec. 8, 1982), translated in THE NOBEL PRIZES 1982 (Wilhelm Odelberg ed., 1983) ("Latin America neither wants, nor has any reason, to be a pawn without a will of its own; nor is it merely wishful thinking that its quest for independence and originality should become a Western aspiration.").

3. The term "Latin America" technically refers to the former colonies of "Latin" nations, such as Spain, Portugal and France. Nowadays, however, it usually denominates Ibe- 
America has recently started acting fiercely independently and originally with respect to the law. It has, once and again, broken with the past, created unprecedented possibilities and positioned itself to influence the rest of the world. This paper investigates this general phenomenon in the context of collective suits. It principally focuses on the Brazilian legal system, which has displayed the most innovativeness in this area, but also turns to other jurisdictions in order to illustrate the breadth of this development.

Accordingly, the present inquiry casts aside the usual clichés of Latin America as a land of chaos, oppression, lawlessness and hopelessness. It shows a radically different and oft-neglected side of the coin. At the same time, it resists the luring temptation to depict the region as a monolithic whole. The article takes pains to underscore the profound legal diversity that permeates this vast territory. It identifies transnational trends but stresses that the specific form that they take and the extent of their pervasiveness vary enormously from one country to the next.

The aim of the discussion is not merely to describe representative litigation south of the border, but rather to select certain promising aspects and thereupon imagine a new and improved praxis. Inasmuch as this approach concentrates on existing institutions and on their possible reformation, transitioning from what is to what might and should be, it requires proceeding both descriptively and normatively (perhaps more in the latter than in the former fashion).

This work expounds the thesis that Latin America has launched a true revolution on collective rights: moving beyond the paradigm of group entitlements, which concern a determinatethough potentially enormous-collectivity, to that of comprehensive

rian America and thus refers only to the New World territories colonized by the nations that occupy the Iberian peninsula, i.e., Spain and Portugal. This paper deploys the term "Latin America" in this contemporary, albeit inaccurate, sense. It makes use of the more precise, but less current, expression "Iberian American" only intermittently. It thus seeks to maintain the former as familiar and readily comprehensible, while gradually introducing the latter.

The piece focuses on Iberian American countries because, as partial cultural descendants of nations that share so much history, they evince considerable coherence in their conceptions of rights. Former Spanish and Portuguese colonies converged legally during colonial times and frequently developed their law under the influence of each other after independence. They certainly overlap with countries formerly colonized by France more so than they do with Anglo-American nations, yet undoubtedly less than they do with each other. For instance, some of the key legal institutions, such as the writ of protection (or amparo), prevail in the Iberian American realm, but not in its Franco-American counterpart. 
entitlements, which generally pertain to society as a whole. The former rights, which one might also denominate "communal" or "microcollective," include, for example, those of the inmates of a prison to constitutional incarceration conditions and those of all consumers of tobacco to compensation for ensuing injuries to their health. The latter rights, which one might additionally term "societal" or "macrocollective," encompass, for instance, those of the entire population to a safe environment and those of the citizenry to a fair counting of their votes in an election. This contrast parallels, though only imperfectly, that between second- and third-generation entitlements. ${ }^{4}$ For present purposes, the adjectives "collective," "trans-individual," "meta-individual" and "representative" not only share a wider range of application than the two categories just distinguished, but also encompass both of them as subsets.

Latin American nations have taken an initial, almost rhetorical step by constitutionally recognizing a new set of substantive micro-collective and macro-collective guaranties. They have then consolidated this shift by creating procedural means to breathe life into these norms. This essay predominantly pores over this second move.

Specifically, the argument advanced demonstrates how Iberian American legal systems-most conspicuously, that of Brazilhave taken the idea of trans-individual entitlements and processes, mainly from the United States, and radically transformed it. They have established causes of action inspired by the U.S. class action, but based on autochthonous institutions, in order creatively to process group rights. Additionally, they have designed procedural means for the vindication of comprehensive guarantees.

Latin American jurisdictions have often empowered nongovernmental organizations and individuals to defend communal, as well as societal, rights in court. They have also vested this prerogative in independent state entities, such as public ministries, which have taken on a paramount role in this area. This paper calls for a consolidation and intensification of these efforts.

The U.S. legal world has much to learn from the transformation taking place in the southern continent. It could, first, put forth a new provision to enable any concerned person or association to vin-

4. See infra Part II for further discussion of this matter.

5. Part IV introduces the Public Ministry as an autonomous state institution in charge, throughout Latin America, of defending the public interest in and out of court. 
dicate comprehensive entitlements through a universally available citizen's suit. It could, second, institute an autonomous state body, along the lines of the Procurator General's Office, ${ }^{6}$ with power to file complaints on behalf of communal, as well as societal, interests. Third, U.S. rule-making authorities could grant standing to organizations as well as individuals to pursue class suits. They could, finally, re-engineer and enhance Rule 23 of the Federal Rules of Civil Procedure by positing a single, straightforward classification under 23(b). A complete analysis of these suggestions would, of course, outrun the limits of the endeavor at hand.

After this introduction, Part II will probe into the concept of collective litigation and place it in comparative perspective. Part III will present the collective writ of protection as an instrument for the implementation of group rights and recommend that, beyond associations, individuals also have the right to initiate such litigation. Part $\mathrm{IV}$, in turn, will discuss the popular action as a procedural device through which individuals may realize certain comprehensive entitlements. It will propose enlarging the scope of the suit to incorporate all such rights and permitting organizations to sue. Further, Part $\mathrm{V}$ will explore the deployment of public civil actions by the public ministry to enforce micro- and macro-collective entitlements. It will support streamlining the procedure by defining the safeguarded guarantees less rigidly and by expanding the preclusion effects. Parts III, IV and $\mathrm{V}$ will advocate, on similar grounds, the imposition of an adequacy-of-representation requirement on each one of these suits. Part VI will recommend specific changes to U.S. law inspired by these three procedural actions, along the lines traced in the previous paragraph. Finally, Part VII will conclude, ultimately pointing to and reflecting upon the still-existing impediments to the realization of collective rights in the southern continent.

This investigation is part of a larger project, which identifies a set of remarkable accomplishments in the Iberian American struggle for rights and envisions a brighter future. The successes in question are the vigorous enforcement of positive entitlements, the creation of key specialized procedures and the domestication of international guarantees. The underlying and unprecedented theoretical premise is that one must consider rights integrally or organically and analyze not only negative, substantive and national entitlements, but also

6. As explained in Part IV, the Procurator General heads the Public Ministry. 
their positive, procedural and international counterparts.

The following study scrutinizes one of the special procedures that have emerged for the implementation of legal entitlements. The mechanism under scrutiny, i.e., the meta-individual suit, has attained prominence partly - and somewhat paradoxically - as a way to compensate for the deficiencies of ordinary process. It thus resembles other causes of action, such as the writ of protection or the unconstitutionality claim. $^{7}$

This paper does not ignore, but rather calls attention to, the defects of the structures under consideration. It unfolds, moreover, in full awareness that Latin American law generally operates against an adverse backdrop of weak adherence to paramount ideals such as the rule of law, democracy, personal freedom, and solidarity. The achievements at stake, consequently, face a constant threat. The conclusion of this piece will examine these issues. It will suggest ways to address these all-but-impossible challenges and will insist, in the spirit of Paul Gauguin, on keeping paradise in sight despite the hellish conditions occasionally found in situ. ${ }^{8}$ Nonetheless, a full examination of this most complex problem would require considerably more deliberation and will therefore have to wait for a later moment.

\section{COllective Litigation: CONCEPT AND COMPARATIVE CONTEXT}

Unlike the amparo or writ of protection, ${ }^{9}$ the Latin American collective action did not originate indigenously. Instead, it mostly emerged abroad, eventually migrated to Iberian America and ultimately underwent an idiosyncratic development there. It thus resembles the local unconstitutionality suit, although the latter has its roots mainly in Continental Europe and the former principally in the United States.

On first impression, the phrase "collective lawsuit" merely suggests litigation involving multiple plaintiffs. From this perspec-

7. Part III discusses further the writ of protection, a specialized mechanism for the vindication of constitutional and other rights, as well as the unconstitutionality suit, an action through which courts conduct abstract judicial review.

8. See GAUGUIN, infra note 150 , and accompanying text.

9. Part III will further discuss this institution, which was introduced in note 7 and accompanying text. 
tive, a complaint filed jointly by two individuals would fall under the category. In Latin America, the term "litisconsorcio," in both Spanish and Portuguese, points etymologically to a "consortium in litigation" and refers to a scenario in which various parties litigate together. It encompasses aggregations of not only plaintiffs, but also defendants. The litigants may be part of the group from the outset or may enter the suit through necessary or permissive joinder. ${ }^{10}$

This article deploys the expression "collective action" in a different sense. It examines lawsuits that affect the rights of a multiplicity of individuals who, for the most part, never actually appear in court. These absent beneficiaries may even be unaware that the proceedings are taking place.

These representative causes of action break down into two subcategories: group suits and comprehensive suits. The former concentrate on the rights of a determinate, though potentially huge, micro-collectivity, such as the student body of a college or the victims of asbestosis. The latter focus on the entitlements of a virtually boundless macro-collectivity, viz., society as a whole, with respect to environmental, developmental, or other matters. Even though these classifications defy any precise definition and overlap considerably, they point to real and crucial distinctions.

The rights at stake roughly correspond to what Karel Vašák famously denominates second- and third-generation rights. " Firstand second-generation rights are associated, respectively, with the 1966 United Nations' International Covenants on Civil and Political Rights and on Economic, Social and Cultural Rights. ${ }^{12}$ They encompass, on the one hand, mainly individual entitlements such as equality, due process, privacy, free speech, liberty of association, as well as universal suffrage, and, on the other hand, mostly group rights to work, to unionize, to subsistence, to housing, to health, to education

10. See, e.g., FED. R. CIV. P. 19; FED. R. CIV. P. 20.

11. Karel Vašák, Les différentes catégories des droits de l'homme, in 1 LES DIMENSIONS UNIVERSELLES DES DROITS DE L'HOMME 297 (André Lapeyre, François de Tinguy \& Karel Vašák eds., 1990); see also Louis B. Sohn, The New International Law: Protection of the Rights of Individuals Rather Than States, 32 AM. U. L. REV. 1 (1982).

12. International Covenant on Civil and Political Rights, Dec. 16, 1966, 999 U.N.T.S. 171 (entered into force Mar. 23, 1976) (the provisions of article 41 (Human Rights Committee) entered into force Mar. 28, 1979); Optional Protocol to the International Covenant on Civil and Political Rights, Dec. 16, 1966, 1057 U.N.T.S. 407 (entered into force Mar. 23, 1976); International Covenant on Economic, Social and Cultural Rights, Dec. 16, 1966, 993 U.N.T.S. 3 (entered into force Jan. 3, 1976). 
and to culture. Third-generation rights, in turn, are basically comprehensive entitlements that have gained recognition subsequently and that regard matters such as self-determination, environment, development, and information. ${ }^{13}$

The two categorizations - i.e., by breadth of impact, from individual to societal, and by generational identification, from first- to third-generation - coincide only partially. Some second-generation guaranties, such as the right to health, most frequently take a societal form. Certain third-generation entitlements, like consumer rights, most commonly affect a determinate collectivity. These key divergences notwithstanding, the two conceptual schemes help illuminate each other.

The U.S. class action constitutes a micro-collective procedure par excellence. A few individuals act as representatives of an extended group and thus bind their fellow class members. They must show, inter alia, that their claims are typical and that they will adequately represent everyone else in the class. ${ }^{14}$

The class suit is an age-old creature of equity procedure within the common-law tradition. ${ }^{15}$ It attained prominence in the United States in the second half of the twentieth century as a means to compensate mass tort victims and reform public institutions. It faced considerable backlash in the 1970 s, as opponents criticized the judicial implementation of these ends and claimed that rampant abuse had taken place. ${ }^{16}$ This challenge, which continues to this day, has led to key modifications in the text and interpretation of the relevant rule. ${ }^{17}$ Nonetheless, the class action remains a crucial device for the

13. See generally Jack Donnelly, Third Generation Rights, in PEOPLES AND MINORITIES IN INTERNATIONAL LAW 119, 134-37 (Catherine Brolmann, Rene Lefeber \& Marjoleine Zieck eds., 1993).

14. See Fed. R. Civ. P. 23(a).

15. Ortiz v. Fibreboard, 527 U.S. 815, 833 (1999) ("[C]lass actions as we recognize them today developed as an exception to the formal rigidity of the necessary parties rule in equity ... as well as from the bill of peace, an equitable device for combining multiple suits."); Amchem v. Windsor, 521 U.S. 591, 613 (1997) ("Rule 23, governing federal-court class actions, stems from equity practice and gained its current shape in an innovative 1966 revision.").

16. See Owen M. Fiss, The Political Theory of the Class Action, 53 WASH. \& LEE. L. REV. 21, 30 (1996) ("In the 1970s and 1980s, American politics and American law moved to the Right, and, in that climate, the class action became a frequent target of conservative forces.").

17. The U.S. Supreme Court has interpreted procedural rules and statutes restrictively with respect to class actions. See generally Snyder v. Harris, 394 U.S. 332 (1969) (prohibit- 
vindication of group rights.

In the United States, an association-such as a union, club or political party - may have an impact similar to that of class delegates when it litigates on behalf of its membership. It must first show, according to the U.S. Supreme Court, that "its members would have standing to sue in their own right," that "the interests at stake are germane to the organization's purpose" and that "neither the claim asserted nor the relief requested requires individual members' participation in the lawsuit." 18 The judgment generally binds the membership, except in cases of inadequacy of representation. ${ }^{19}$

The government and its agencies, such as the Equal Employment Opportunity Commission, may also seek class-wide remedies in the United States. ${ }^{20}$ In these suits, however, the final decision usually does not preclude subsequent litigation by the individual claimants. The U.S. Supreme Court justifies this restriction, at least in labor discrimination cases, by pointing to a legislative "intent to accord parallel or overlapping remedies" and to "the possible differences between

ing the aggregation of members' claims in diversity class actions in order to satisfy the amount-in-controversy requirement); Zahn v. Int'l Paper Co., 414 U.S. 291 (1973) (holding that each member in diversity class actions must meet the amount-in-controversy prerequisite); Eisen v. Carlisle \& Jacquelin, 417 U.S. 156 (1974) (requiring 23(b)(3) class action representatives to notify all members individually and to pay the entire cost of notification); Amchem v. Windsor, 521 U.S. 591 (1997) (insisting on strict compliance with the adequacy of representation and predominance of commonality requirements in 23(b)(3) settlement class actions); Ortiz v. Fibreboard, 527 U.S. 815 (1999) (requiring representatives in a settlement $23(\mathrm{~b})(1)(\mathrm{B})$ class action clearly to prove the fund's limit and to address any conflicting interest among members). Recent amendments to the Federal Rules of Civil Procedure have increased the appellate supervision of class certification decisions, FED. R. CIV. P. 23(f) (amended 1998), as well as the trial court's control over appointment and compensation of class counsel, FED. R. CIV. P. 23(g), (h) (amended 2003), and granted dissident members the right to object and a new opportunity opt out $v i s-\grave{a}$-vis settlement proposals, FED. R. CIV. P. 23(e) (amended 2003). Furthermore, the 2005 Class Action Fairness Act authorizes removal from state courts of class actions that satisfy minimal diversity requirements and that seek more than $\$ 5,000,000$ in damages. 28 U.S.C. $\$ \S 1453,1332$ (d) (2006). Finally, Congress enacted special restrictions on representative plaintiffs and attorneys in securities class actions. Private Securities Litigation Reform Act of 1995, 15 U.S.C. $§ 77 z-1$ (2000).

18. Friends of the Earth, Inc. v. Laidlaw Envtl. Servs. (TOC), Inc., 528 U.S. 167, 181 (2000) (citing Hunt v. Wash. State Apple Adver. Comm'n, 432 U.S. 333, 343 (1977)).

19. If an association does not "represent adequately the interests of all their injured members . .. , a judgment won against it might not preclude subsequent claims by the association's members without offending due process principles." Int'l Union v. Brock, 477 U.S. 274, 290 (1986).

20. See Judith Resnik, From "Cases" to "Litigation", 54 LAW \& ConTEMP. ProBs. 5, 35 (Summer 1991) ("Aggregate litigation also occurs when statutes authorize a government official to pursue litigation on behalf of a group. A myriad of federal statutes create such opportunities."). 
the public and private interests involved." 21 A further justification might rest on the fact that these state litigants may sue for the benefit of individuals with conflicting interests and, accordingly, inadequately represent the ultimate beneficiaries. ${ }^{22}$

Historically, the European Continent has not experienced quite as much pressure to attain the same compensatory and reformative objectives through the law, partly because it has a more solid social insurance system and has thus far confronted less extreme crises within its educational, correctional and other structures than the United States. $^{23}$ In contrast, Iberian America has fared even worse on these fronts than its northern neighbor. For example, it has run into greater problems of insufficient indemnification for widespread injuries, inhumane prison conditions and unequal access to education. Nonetheless, when it has responded at all, it has traditionally done so politically rather than judicially. ${ }^{24}$

As a result, group suits have historically played a relatively modest role in Continental Europe and Latin America. Legal reform-

21. Gen. Tel. Co. v. EEOC, 446 U.S. 318, 333 (1980) (quoting Alexander v. GardnerDenver Co., 415 U.S. 36, 47 (1974)).

22. The U.S. justices have noted, for example, that "the EEOC is authorized to proceed in a unified action and to obtain the most satisfactory overall relief even though competing interests are involved and particular groups may appear to be disadvantaged." Id. at 331.

23. See James A. Morone, Political Accountability: The Bias of American Politics: Rationing Health Care In A Weak State, 140 U. PA. L. REv. 1923, 1925 (1992) ("Americans developed their social insurance programs far more reluctantly than did most Western democracies. In Europe, benefits were generally proffered from the political center by statesmen bidding for the allegiance of workers."); MARY ANN GLENDON, ABORTION AND DiVORCE IN WESTERN LAW: AMERICAN FAILURES, EUROPEAN CHALlENGES 136 (1987) ("Throughout Western Europe today it is taken for granted that governments are responsible for public welfare; that they insure health employment, and retirement; and that they will do so at more than minimal levels.").

24. In Brazil, for instance, the most conspicuous attempt to address the unconstitutionality of incarceration conditions was a presidential decree, Decreto No. 1.904, de 13 de Maio de 1996, D.O. de 14.05.1996 (Braz.), while São Paulo authorities headed the effort to obtain compensation from the airline TAM after the deadly accident of July 2007. See Elaine Patricia Cruz, Cinco meses após acidente com avião da TAM, parentes ainda esperam indenizações, AGÊNCIA BRASIL, Dec. 21, 2007, available at http://www.agenciabrasil.gov. $\mathrm{br} /$ noticias/2007/12/17/materia.2007-12-17.8479365035/view. The federal government, in turn, sent a law to Congress in order to regulate the reparations to victims in future air calamities. See Leonel Rocha, Governo quer critérios pra indenizar vítimas, CORREIO BRAZILIENSE, Feb. 29, 2008, available at http://pfdc.pgr.mpf.gov.br/clipping/fevereiro2008/governo-quer-criterios-pra-indenizar-vitimas. The Mexican endeavor to confront educational discrimination against indigenous peoples through legislation, rather than litigation, provides another example. See Ley Federal Para Prevenir y Eliminar la Discriminación [Federal Law to Prevent \& Eliminate Discrimination], Diario Oficial de la Federación [D.O.], 11 de Junio de 2003 (Mex.). 
ists in both regions, however, have recently started calling for change. In particular, they have propounded the broad use of collective litigation to implement not only civil, political, social and economic liberties, but also third-generation rights in areas such as environmental and consumer law. Of course, they have tended to endorse not class actions per se, which are foreign to the civil law universe, ${ }^{25}$ but rather functional equivalents either derived from pre-existing mechanisms or created from scratch.

The Old World has principally responded by authorizing group litigation. A 1998 European Parliament and Council directive, for example, calls for the entitlement of "independent public bodies" and private organizations to seek injunctions for "the protection of the collective interests of consumers." 26 Iberian American jurisdictions, in turn, have often gone much further and enabled the vindication of communal, as well as societal, claims. In this effort, they have opened up at least three different possibilities. First, individuals or organizations may seek a "collective" writ of protection against violations of the rights of a larger collectivity. ${ }^{27}$ (In the context of this paper, one could actually denominate this device "microcollective," as it envisages a societal subgroup.) Second, citizens may file popular actions, which stem from Roman law, in order to defend public assets in the name of the population as a whole. ${ }^{28}$ Third, public ministries, associations and sometimes ordinary people may initiate the increasingly prevalent and U.S.-inspired public civil actions for the judicial enforcement of comprehensive and group rights. $^{29}$

25. Of course, Puerto Rico and Québec constitute exceptions. These two civil law jurisdictions under U.S. and Anglo-Canadian influence, respectively, allow class litigation. See P.R. R. CIV. P. 20; Québec Code of Civil Procedure, R.S.Q., ch. C-25, 999-1026 (Can.).

26. See Council Directive 98/27, arts. 3, 1(1), 1998 O.J. (L 166) 51 (EC).

27. See Lei No. 7.347, de 24 de Julho de 1985, D.O.U. de 25.7.1985. (Braz.); Resolución Ministerial No. 10-93-JUS, 8 Jan. 1993, Texto Unico Ordenado del Código Prosecal Civil (Peru); Ley No. 15.982, 18 Oct. 1988, Código General del Proceso (Uru.).

28. See CONSTITUIÇÃo DA REPÚBliCA FEdERATIVA DO BRASIL DE 1988 [hereinafter Braz. CONST.] art. 5(LXXIII); CONSTITUCIÓN POLÍtiCA DE COlOMBIA DE 1991 art. 88 [hereinafter Colom. Const.]; Constitución Política de la República de Panamá art. 203(2) [hereinafter Pan. Const.]; Constitución Política del Perú art. 200(5) [hereinafter PERU CONST.].

29. Only Brazilians use the term "public civil action." Other Latin Americans speak loosely of "comprehensive interests" actions. See, e.g., Resolución Ministerial No. 10-93JUS, 8 Jan. 1993, Texto Unico Ordenado del Código Procesal Civil (Peru); Ley No. 15.982, 18 Oct. 1988, Código General del Proceso (Uru.). 
The initiative in this realm has mostly stemmed from the legislature, yet the judiciary has occasionally acted on its own. For instance, some tribunals south of the border have created, sua sponte and in the absence of any enabling legislation, a joint writ of protection. For instance, the Argentine Supreme Court established in Ekmekdjián $v$. Sofovich that a plaintiff may assert the right of reply on behalf of many individuals profoundly offended by a statement in the media. $^{30}$ Similarly, in Cruz del Valle Bermúdez v. Ministerio de Sanidad y Asistencia Social [Ministry of Health and Social Welfare], Venezuela's highest tribunal allowed a substantial number of indigent patients with the Human Immunodeficiency Virus (HIV) and the Acquired Immune Deficiency Syndrome (AIDS) to sue on behalf of all similarly situated victims of the disease in order to force the government to provide necessary treatment. ${ }^{31}$

As already suggested, Latin America has revolutionized collective litigation by embracing not only communal procedures but also societal actions. In contrast, U.S. law permits the latter only under limited circumstances, not generally. As explained in Part IV, some federal statutes authorize citizen suits, which enable personally affected plaintiffs to assert the public's interest through litigation. ${ }^{32}$ Similarly, qui tam actions empower individuals only to challenge specific conduct that injures society as a whole, such as the embezzlement of state monies. ${ }^{33}$ The U.S. legal system does not feature a

30. Corte Suprema de Justicia [CSJN], 7/7/1992, "Ekmekdjián, Miguel Angel c. Sofovich, Gerardo y otros / derecho de réplica, acción de amparo, queja por denegación de recurso extraordinario, tratados y convenios internacionales," La Ley [L.L.] (1992-C-542) (Arg.), translated and reprinted in ÁNGEL R. OQUENDO, LATIN AMERICAN LAW 242-58 (2006).

31. Cruz del Valle Bermúdez v. Ministerio de Sanidad y Asistencia Social, Sala Político-Administrativa, Corte Suprema de Justicia, República de Venezuela, Expediente Número: 15,789 (1999), translated and reprinted in OQUENDO, supra note 30, at 335-45.

32. See, e.g., Clean Air Act, 42 U.S.C. $\S 7604$ (2000); Clean Water Act, 33 U.S.C. $\S$ 1365 (2000); Endangered Species Act, 16 U.S.C. $\S 1540(\mathrm{~g})(2000)$; Clayton Antitrust Act, 15 U.S.C. $\S 15(\mathrm{a})(2000)$.

33. See, e.g., False Claims Act, 31 U.S.C. $\S \S 3729-3733$ (2000); Vermont Agency of Natural Res. v. United States ex rel. Stevens, 529 U.S. 765, 769 n.1 (2000) ("Qui tam is short for the Latin phrase qui tam pro domino rege quam pro se ipso in hac parte sequitur, which means 'who pursues this action on our Lord the King's behalf as well as his own.' The phrase dates from at least the time of Blackstone. See $3 \mathrm{~W}$. BLACKSTONE, COMMENTARIES * 160 . Three other qui tam statutes, all also enacted over 100 years ago, remain on the books. See 25 U.S.C. $\$ 81$ (providing cause of action and share of recovery against a person contracting with Indians in an unlawful manner); $\S 201$ (providing cause of action and share of recovery against a person violating Indian protection laws); 35 U.S.C. $\S$ 292(b) (providing cause of action and share of recovery against a person falsely marking patented articles); $c f .18$ U.S.C. $\S 962$ (providing for forfeiture to informer of share of ves- 
statute or a federal rule that broadly enables private parties to sue whenever universally shared interests are at stake.

Iberian American nations have also deviated from the U.S. model to the extent that they have created autonomous state entities and have authorized them, inter alia, to file micro- and macrocollective actions. The European Union has followed a similar path insofar as it has called for the enforcement of consumer suits by "independent public bodies." ${ }^{34}$ The United States, for its part, occasionally entrusts the implementation of group and comprehensive claims to officials and agencies that work at the behest of the administration in power.

Table 1 contrasts collective procedures in the United States and Latin America on the basis of their scope and of the initiating plaintiff. The categories will become more familiar, and consequently clearer, as the discussion unfolds. Individuals vindicate group claims through class actions in the North and through collective writs of protection or security in the South. Organizations do the same through associational suits in the United States and through collective writs in Iberian America. ${ }^{35}$ U.S. governmental agencies, such as the Equal Employment Opportunity Commission or the Securities and Exchange Commission, and self-standing Latin American public ministries may also defend the interests of micro-collectivities, through agency class litigation and public civil actions, respectively.

\section{Table 1. U.S. v. Latin American Collective Procedures Organized by Scope and by Litigant}

\begin{tabular}{|l|l|l|l|}
\hline Scope/Litigant & Individual & Organization & State Entity \\
\hline Group Suit & $\begin{array}{l}\text { Class Action v. } \\
\text { Collective Writ }\end{array}$ & $\begin{array}{l}\text { Associational Suit } \\
\text { v. Collective Writ }\end{array}$ & $\begin{array}{l}\text { Agency Class } \\
\text { Litigation v. Public } \\
\text { Civil Action }\end{array}$ \\
\hline $\begin{array}{l}\text { Comprehensive } \\
\text { Action }\end{array}$ & $\begin{array}{l}\text { Citizen Suit; } \\
\text { qui tam v. } \\
\text { Popular Action }\end{array}$ & $\begin{array}{l}\text { Citizen Suit; } \\
\text { qui tam } \text { v. } \\
\text { Popular Action }\end{array}$ & $\begin{array}{l}\text { Agency Enforcement } \\
\text { Suit v. Public Civil } \\
\text { Action }\end{array}$ \\
\hline
\end{tabular}

sels privately armed against friendly nations, but not expressly authorizing suit by informer); 46 U.S.C. $\S 723$ (providing for forfeiture to informer of share of vessels removing undersea treasure from the Florida coast to foreign nations, but not expressly authorizing suit by informer).").

34. See Council Directive 98/27, arts. 3, 1(1), 1998 O.J. (L 166) 51 (EC).

35. As previously noted, Brazilian non-governmental organizations may also file public civil actions. 
With regard to comprehensive claims, individuals and organizations in the United States may exceptionally file citizen suits or qui tam actions, ${ }^{36}$ as defined by specific statutes, while their Iberian American neighbors may set in motion the more wide-ranging popular action. ${ }^{37}$ U.S. administrative agencies, like the Environmental Protection Agency and the Department of Justice, may launch enforcement procedures, while Latin American public ministries may commence public civil actions. The southern entities, due to their autonomy, are usually in a better position than their northern counterparts to litigate against the interests or wishes of the government.

In Latin America, Brazil has taken the lead in collective litigation in general. Since the 1980 s, it has recognized a wide array of meta-individual causes of action. It has thus created a paradigm that has drawn significant attention throughout the continent. Many Iberian American nations have already produced statutes or legislative bills on the matter, but none of them has gone as far as Brazil in terms of the quantity and quality of the options available.

Latin American juridical systems will most certainly undergo substantial transmutations in this area over the next decade. They will have to find their own way, learning from foreign law without blindly imitating it. Specifically, legal actors in the region should continue to push beyond a narrow, group-rights focus, in order to attend to comprehensive entitlements. Ultimately, they will have to come to appreciate and embrace the law's capacity effectively to realize crucial public values and radically to reconfigure societal relations.

36. U.S. organizations regularly bring citizen suits, see, e.g., Friends of the Earth, Inc. v. Laidlaw Envtl. Servs. (TOC), Inc., 528 U.S. 167 (2000), and may act as the "private person" entitled to file the qui tam action. 31 U.S.C. $\$ 3730$ (b) (2006). See United States ex rel. Lamers v. City of Green Bay, 998 F. Supp. 971,983 (E.D. Wis. 1998) ("[T]here is no case law to suggest that legal entities such as corporations are precluded from maintaining qui tam actions. Law firms have brought successful qui tam suits under the FCA, as have state attorneys general on behalf of individual states.").

37. An Iberian American association would have to encourage someone from its membership to take the role of the "citizen" initiating the popular action. BRAZ. CONST, art. 5(LXXIII). In Brazil, it could, alternatively, file a public civil action to enforce comprehensive rights. 


\section{Collective Writs OF PROTECTION OR SECURITY}

The individual writ of protection developed in Mexico in the nineteenth century in order to enable private parties to claim their legal entitlements. It has gradually and steadily taken hold in other Iberian American legal systems and now exists throughout the continent, from Tijuana to Tierra del Fuego. ${ }^{38}$ Most countries, like Mexico, denominate this action "amparo,", a word that means protection or shelter. The Colombian Constitution uses, instead, the term " $t u$ tela," ${ }^{40}$ which translates into "guardianship" or "defense," while the Chilean charter opts for the phrase "recurso de protección," or (literally) "protection recourse." 41 The Brazilian Constitution, in turn, speaks of a "mandado de segurança," i.e., "security mandate.,"42

Even though the name varies, the underlying procedure remains essentially the same. It enables claimants to vindicate summarily fundamental rights. The court must give priority to these cases and apply a special set of procedural rules. Moreover, the decision

38. See Constitución de la Nación ARgentina $§ 43$ [hereinafter ARg. CONST.]; Constitución Politica del Estado de Bolivia art. 19; BRAZ. Const. art. 5(LXIX); Constitución Política de la RepúbliCa de Chile art. 20 [hereinafter Chile Const.]; COlom. CONST. art. 86; Constitución POlítica de la RePÚblica de Costa Rica art. 48; CONSTITUCIÓN POLITICA DE LA REPÚBliCA DEL ECUAdOR art. 95 [hereinafter ECUAdor CONST.]; CONSTitución de la República dE El Salvador art. 247; CONSTITUCión Politica de la República de Guatemala art. 265; CONSTITUCión Politica dE LA RePública de Honduras art. 183; ConstituCión Política dE los Estados Unidos MEXICANOS [hereinafter MEX. CONST.], art. 103(I), amended by, Diario Oficial de la Federación [D.O.], 5 de Febrero de 1917 (Mex.); Constitución Política de la RepúbliCa dE NiCARAgua art. 188; PAN. Const. art. 50; Constitución de la República del Paraguay art. 134 [hereinafter PARA. CONST.]; PERU CONST. art. 200(2); Ley No. 16.011, 19 Dec. 1988, Accion de Amparo, Diario Oficial de la República Oriental del Uruguay [D.O.], 29 Dec. 1988 (Uru.); CONSTITUCIÓN DE LA RePúBliCA Bolivariana de VenEZUELA art. 27 [hereinafter VENEZ. CONST.]. In the Dominican Republic, the Supreme Court recognized the writ on February 24, 1999. Productos Avon, Inc. v. 2nd Ch., Labor Ct., Nat. Dist. [Sup. Ct.] (Dom. Rep.) (1999). The Cuban Constitution does not recognize the writ, but rather a generic "right to address complaints and petitions to the authorities and to receive a reasonably timely response, according to the law." CONSTITUCIÓN DE LA REPÚBLICA DE CUBA art. 63. Finally, Puerto Rico's constitutional charter, which essentially reproduces its U.S. counterpart, does not provide for a protection suit. Consequently, Puerto Ricans vindicate their rights through ordinary civil complaints.

39. See Mex. ConST., art. 107, as amended, D.O., 5 de Febrero de 1917 (Mex.).

40. Colom. Const. art. 86.

41. Chile CONST. art. 20. Curiously, Chilean lawyers use the word "amparo" to denominate the writ of habeas corpus. See, e.g., JoRGE MARIO QuINZIO FIGUEIREDO, JuSTICIA CONSTITUCIONAL EN CHILE 78-79 (2000).

42. BRAZ. CONST. art. 5(LXIX). 
typically concerns only the litigants. Consequently, the judge may hold the challenged act or law unconstitutional in the case at hand but does not establish a precedent. Another individual subsequently facing a similar situation would have to re-litigate the issue. She may naturally cite the preceding opinion as a source of persuasive reasons, but not as a binding norm. ${ }^{43}$

Of course, the details vary enormously from one country to the next. In Argentina and Brazil, for instance, the proceeding unfolds strictly summarily and admits exclusively documentary proof. ${ }^{44}$ The tribunal basically treats the request for the writ as a motion for summary judgment. In Mexico and most other jurisdictions, the parties may introduce all kinds of evidence, including testimony. Furthermore, Latin American systems diverge on matters such as whether the suit lies only against state action, whether it applies solely to constitutional rights and whether it admits challenges to judicial decisions. Finally, Argentina and Paraguay, unlike the rest of their regional neighbors, generally authorize judges to invalidate unconstitutional statutes in these causes. ${ }^{45}$

Many Latin American jurisdictions have established a collective writ of protection or security. ${ }^{46}$ A plaintiff may request such a

43. See, e.g., Ley de amparo, reglamentaria de los articulos 103 y 107 de la Constitucion politica de los Estados Unidos Mexicanos [Amparo Law], art. 76, D.O., 10 de Enero de 1936 (Mex.), translated and reprinted in OQUENDO, supra note 30, at 267: "The protection judgment shall concern only the claimants, whether individuals, private entities, or public officials. It shall restrict itself to protecting them in the context of the specific case referred to in the complaint. It shall not make a general declaration with respect to the challenged law or action." The Mexican Supreme Court, however, may issue case law in these controversies after consecutively deciding the same issue in five opinions in a row and through a super majority either of eight out of the Plenum's eleven justices or, alternatively, of four out of a Chamber's five justices. See id. art. 192, translated and reprinted in OQUENDO, supra note 30, at 267 ("Supreme Court holdings shall constitute case law if supported by five consecutive, uninterrupted decisions, which at least eight justices of the Plenum or four justices of the competent Chamber have approved."). Mexico's Courts of Appeals may also establish binding precedents. See id. art. 193, translated and reprinted in OQUENDO, supra note 30, at 267 ("The holdings of circuit court panels shall constitute case law if supported by five consecutive, uninterrupted, and unanimous decisions.").

44. The Argentine Writ of Protection Act declares the action inadmissible "whenever determining the alleged invalidity of the act would require broad argumentation or introduction of evidence." Law No. 16986, art. 2(b), Oct. 18, 1966, B.O. 20-X-1966. Brazil's Constitution, in turn, establishes that the writ lies to protect "summarily and clearly ascertainable" entitlements. BRAZ. CONST. art. 5(LXIX).

45. Arg. Const. art. 43; Código Procesal Civil [Cód. Proc. Civ.] art. 582 (Para.).

46. See, e.g., Braz. CONST. art. 5(LXX); ECUAdOR CONST. art. 95; MEX. Const. arts. 2(A)(VIII) (indigenous rights), 107(II) (communal agrarian rights), as amended (Mex.); PARA. CONST. art. 38; VENEZ. CONST. art. 26; Decreto 2591 de 1991, art. 6(3), 19 Nov. 1991, 
writ in order to protect the prerogatives of an entire group. In Brazil, for example, political parties, unions and organizations have standing, yet a person on her own does not. ${ }^{47}$ Argentina's 1994 Constitution empowers, on the one hand, "individuals affected" and, on the other hand, the "People's Defender" to file such actions. ${ }^{48}$ It thus creates the equivalent of a U.S. class action and a Brazilian microcollective public civil action, respectively. In other words, one or several representatives or an independent public organ ${ }^{49}$ may initiate a collective "defense of environment, competition, and consumer rights, as well as collective rights more generally." Argentine and Brazilian plaintiffs must make their case mostly on the basis of written evidence, inasmuch as they are pursuing, respectively, a writ of protection and a writ of security under the applicable local rules. In most other Iberian American jurisdictions, however, complainants may additionally rely on other means of proof.

Not surprisingly, Latin American organizations have taken advantage of this implementation mechanism and have forced the judiciary to detail the procedural parameters. In FEBRAC v. Presidente da República, for instance, the Brazilian Federation of Syndicates and Associations of Maintenance and Conservation Companies (FEBRAC) sought a collective writ of security on behalf of its membership against the federal executive. ${ }^{51}$ It challenged "Law 8.800 of May 27, 1994, and Provisory Measure 635 of September 27, 1994, [which established] the Program of Economic Stability, the National Monetary System, and the Institution of the Currency Real Unit of Value (RUV)., ${ }^{, 52}$ The plaintiff contended that the change of the official currency from cruzeiros to reais under these provisions violated the contractual rights of its constituents. It argued, in essence, that the value of the contracts under consideration decreased as a consequence of the conversion statute.

The Brazilian Supreme Court dismissed the suit, accusing the

Por el cual se reglamenta la acción de tutela consagrada en el artículo 86 de la Constitución Política (Colom.); Ley No. 7135, art. 67, 11 Oct. 1989, Ley de la Jurisdicción Constitucional, D.O., 19 Oct. 1989 (Costa Rica).

47. Braz. Const. art. 5(LXX).

48. ARG. CONST. art. 43.

49. Id. art. 86.

50. Id. art. 43.

51. FEBRAC v. Presidente da República, S.T.F., MS-22132, Relator: Min. Velloso, 21.8.1996 (Braz.), translated and reprinted in OQUENDO, supra note 30, at 721-25.

52. Id. 
complainant of illegitimately purporting to use the writ of security against a law in the abstract, instead of against a concrete act of implementation. The justices explained that this kind of claim had to take place through an unconstitutionality action. ${ }^{53}$ They thus not only construed the writ of security most restrictively but also left the petitioners with no options. The statute of limitations for an unconstitutionality complaint had most likely already run out and, in any case, the plaintiff did not fall within the limited category of parties that may file such a suit. Article 103 of Brazil's Constitution permits only the president, the legislature, state governors, the procurator general, the Brazilian Bar Association, political parties and national unions to contest abstractly the constitutionality of statutes. ${ }^{54}$

Prior to the settlement of the merits, the FEBRAC Court first had to decide whether the plaintiff had standing. The association at stake was not appearing for itself, but rather on behalf of its members. It purported to defend their collective, rather than their individual, interests. Under the Constitution, it had to be "legally organized and in operation for at least one year" $" 55$ in order to proceed.

The summary of the opinion in FEBRAC reads: "Unions, classes, and associations have extraordinary standing to request a [collective] writ of security." ${ }^{26}$ The Court specifically held that these entities did not need "express authorization" from their membership and that "procedural substitution [took] place." It accordingly let the plaintiff represent its members' joint interests, to stand in for them procedurally, and to bind them without explicitly consulting them.

Consequently, a collective security process launched by an association differs from an ordinary organizational action, in which the decision for or against the organization usually does not bind the members, unless they appear as co-plaintiffs or intervenors. Of course, in the latter kind of procedure, as in the former, the judgment normally has an impact on subsequent litigation. For instance, if FEBRAC had lost in a regular suit instead of a collective security action, the President could have invoked such judicial determination as

53. See generally id. (Opinion by Velloso, J.).

54. BRAZ. CONST. art. 103.

55. Id. art. 5(LXX).

56. FEBRAC v. Presidente da República, S.T.F., MS-22132, Relator: Min. Velloso, 21.8.1996 (Braz.), translated and reprinted in OQUENDO, supra note 30, at 721.

57. Id. 
a source of persuasive reasons, but not as res judicata, against any complaint filed thereafter by particular maintenance companies. As the litigation actually unfolded, he prevailed against the plaintiff's petition for a collective writ and therefore would have been able to preclude any subsequent individual suits.

Coincidentally, Article 5(XXI) of Brazil's Constitution creates a representative associational action that similarly binds members of the plaintiff organization so long as they expressly authorize the litigation. In AJURIS v. Estado do Rio Grande do Sul, the Supreme Court allowed the Association of Judges of Rio Grande do Sul (AJURIS) to file such a suit on behalf of the entire membership, inasmuch as the group had secured majority approval in an extraordinary meeting. ${ }^{58}$ The tribunal rejected the State's argument that the complainant, which was seeking a cost-of-living adjustment on overdue judicial salaries, could only represent those judges who had expressly and individually consented to the action. ${ }^{59}$ As a consequence of this rejection, any member of AJURIS could have subsequently demanded enforcement of the decision, which ultimately upheld the claim, as res judicata.

This type of associational action actually occupies a middle point between the collective writ of security and an ordinary suit in terms of its binding force. It differs from the former, which has an automatic preclusive effect on the plaintiff's membership, as well as from the latter, which demands individual consent in order to bind the members. As noted above, the associates must authorize the litigation filed under Article 5(XXI) not individually, but rather collectively by majority vote, in order to set the suit in motion.

Of these three possibilities, the security suit resembles the previously mentioned U.S. associational action the most. In light of the extensive res judicata consequences, Brazilian judges should, de lege ferenda, consider adequacy of representation prior to the admission of a complaint under Article 5(LXX), for a collective writ of security, or under Article 5(XXI), for an authorized organizational action. Of course, U.S. judges should do the same when confronted with an associational suit purporting to preclude individual litigation by the members.

58. AJURIS v. Estado do Rio Grande do Sul, S.T.F., AO-152, Relator: Min. Velloso, 15.9.1999 (Braz.), translated and reprinted in OQUENDO, supra note 30, at 728-43.

59. Id. 
Occasionally, Latin American tribunals have, sua sponte and without any legislative authorization, issued collective writs of protection for specific types of claims. For instance, before the establishment of the writ through the 1994 constitutional reform, Argentina's Supreme Court determined in Ekmekdjián v. Sofovich that a plaintiff could assert the right of reply on behalf of many individuals profoundly offended by a statement in the media. ${ }^{60}$ The petitioner, a prominent constitutional and international law professor and a devout Catholic, objected to a television show, which featured some jokes about Jesus and the Virgin Mary, as insulting to his faith and sought an opportunity to respond on air. The judicial majority entitled him to speak for himself and for others similarly upset by the televised comic routine:

When someone exercises this right of reply to the words of the offender, the remedial effect will doubtless benefit the entire group of those who feel equally offended. The legislature-or the judiciary in case of legislative neglect-should establish conditions for the exercise of this right in order to preclude an endless number of responses. Unlike those who demand a correction or reply to defend their personal and exclusive rights, the person replying in cases such as the one at hand becomes, in a sense, a collective representative. This person is entitled to undertake this representation by virtue of being the first to bring the claim to the offending broadcaster. The broadcaster will be able to reject subsequent claims of the same or a similar nature simply by establishing that it has already aired a remedial response. ${ }^{61}$

The opinion thus attempts to forestall the eruption of a myriad of complaints each time the media offends widely shared religious beliefs. It prescribes that the first plaintiff person to sue be the only party with standing and act as a representative of all other people who feel similarly injured by the disseminated statements. It binds

60. Corte Suprema de Justicia [CSJN], 7/7/1992, "Ekmekdjián, Miguel Angel c. Sofovich, Gerardo y otros / derecho de réplica, acción de amparo, queja por denegación de recurso extraordinario, tratados y convenios internacionales," La Ley [L.L.] (1992-C-542) (Arg.), translated and reprinted in OQUENDO, supra note 30, at 242-58.

61. Id. ๆ 25. 
the "beneficiaries" to the original determination, if favorable to the plaintiff.

While the spokesman in this controversy alleged that the contested statements impinged upon him personally, he did not have to show that he would adequately represent others. The latter could, accordingly, cry "foul" if they deemed his performance in court or in the media unsatisfactory. Once again, the Argentine justices should have demanded such a showing, perhaps in the manner of U.S. Federal Rule of Civil Procedure 23(a)(4). ${ }^{62}$ If they had, the lawsuit introduced would operate as a class action in the United States, inasmuch as it satisfies, ex hypothesis, the other three prerequisites under the provision in question. In other words, the enormous number of affected individuals would render joinder impracticable, there are common questions of law and fact, and the litigant's claim resembles those of everybody else. ${ }^{63}$

Otherwise, this collective right-of-reply suit procedurally parallels class actions filed in the United States to obtain equitable relief, since it seeks the equivalent of an injunction ordering the defendant to enable the plaintiff to issue his or her response. ${ }^{64}$ It clearly diverges from U.S. class suits characterized by a predominance of common factual issues, ${ }^{65}$ inasmuch as it imposes no individual notification prerequisite and does not allow dissidents to opt out. ${ }^{66}$

In Venezuela, Cruz del Valle Bermúdez v. Ministerio de Sanidad y Asistencia Social [Ministry of Health and Social Welfare] provides another case in point. ${ }^{67}$ A number of indigent patients with HIV and AIDS sued to force the government to provide necessary treatment. The Supreme Court enjoined the authorities to afford the prescribed medications not only to the numerous plaintiffs and intervenors, but also, "in light of the seriousness of the underlying public health crisis," 68 to any similarly situated Venezuelan citizen or resident. It thus converted, sub silentio, an ordinary writ of protection

62. FED. R. CIV. P. 23(a)(4).

63. Compare FED. R. Civ. P. 23(a)(1)-(3).

64. See FED. R. CIV. P. 23(b)(2).

65. See FED. R. CIV. P. 23(b)(3).

66. See FED. R. CIV. P. 23(c)(2)(B).

67. Cruz del Valle Bermúdez v. Ministerio de Sanidad y Asistencia Social, Sala Político Administrativa, Corte Suprema de Justicia, Republica de Venezuela, Expediente Numero: 15,789 (1999) (Venez.), translated and reprinted in OQUENDO, supra note 30, at 335-45.

68. Id., Analysis (Right to Health, Life, and Access to Science and Technology). 
into a collective one.

The justices ultimately granted not only group relief, but also a comprehensive remedy, insofar as they ordered the defendant to adopt a wide-ranging preventive program. They made specific proposals on this issue:

The state must develop a national prevention program along the following lines:

- Educational programs to target vulnerable groups, teenagers, married couples with problems, etc.

- Massive provision of information for the community on the disease, its causes, its transmission, and its prevention.

- Elaboration of a national plan to make affordable diagnoses possible through the state's medical institutions.

Each of these programs requires special preparation and implementation, taking into account matters such as the general information currently available about the disease, the adequate use of condoms, and the availability of sterile syringes for drug users; the need for special attention for vulnerable groups; the existing efforts at the level of the community; and the role of marriage counseling. 69

"The goal must be," the tribunal insisted, "to develop a policy of prevention based on facilitating information to individuals infected with HIV/AIDS, as well as on raising their level of awareness, educating them, and providing comprehensive assistance to them."70

Venezuela's 1999 Constitution created a new Supreme Court (Tribunal Supremo de Justicia), ${ }^{71}$ which soon faced additional claims by HIV/AIDS patients. In López $v$. Instituto Venezolano de los Seguros Sociales [Venezuelan Institute for Social Security], a multiplicity of infected contributors filed a complaint against the Institute for Social Security for failing to pay and deliver prescribed medicines. ${ }^{72}$ The new tribunal, through its Constitutional Chamber, echoed its

69. Id.

70. Id., Decision (3).

71. See VENEZ. CONST. art. 253.

72. López v. Instituto Venezolano de los Seguros Sociales, Sala Constitucional, Tribunal Supremo de Justicia, Expediente Numero: 1,343 (2001) (Venez.), translated and reprinted in OQUENDO, supra note 30, at 346-49. 
predecessor when it found that the defendant had "violated the right to health, threatened the right to life, and encroached upon the right to benefit from scientific and technological progress." 73 The Court similarly rejected the contention that lack of funds or credits might justify the Institute's inaction. ${ }^{74}$

This time, the justices stated that they had recently created and that they would now grant, ex proprio motu, the collective writ of protection:

Even though statutory law does not recognize a judicial action to vindicate collective entitlements or interests and plaintiffs therefore did not file such a suit in the case at bar, the complaint actually calls for the safeguard of a collective right, i.e., that of the aggrieved parties. We treat this claim as a petition for a collective writ of protection, which this Chamber generally authorized in [Defensoría del Pueblo v. Comisión Legislativa Nacional, Exp. No. 1728,] on June 30,2000 .

The opinion even acknowledges the shift from a micro- to a macrocollective procedure:

Such a collective or comprehensive writ may benefit, on the one hand, an aggregation of people that is clearly identifiable as a social group or, on the other hand, an a priori indeterminate multiplicity of individuals that becomes determinate through the specific legal situation and violation faced by the members. ${ }^{76}$

The procedural device in question resembles, in this sense, a public civil action.

The collective writ of protection could potentially play an enormous role in the realization of entitlements pertaining to the citizenry as a whole or, at least, to a considerably large group of people.

73. Id., Considerations (II).

74. Id., Considerations (III).

75. Id., Considerations (IV).

76. Id. Presumably the Court did not have to create the collective writ of protection, since it could have found it in Article 26 of the Constitution. VENEz. CONST. art. 26 ("Every person has a right to access the organs of justice for the protection of his or her entitlements and interests, even if collective or comprehensive, to an effective defense of these goods, and to obtain a prompt decision on the merits."). 
An organization to which most or all of the impacted individuals belong can normally best defend the rights at stake. Nonetheless, the leadership may adopt a particular litigation strategy or choose not to sue at all on the basis of its own priorities and against those of its membership. The law should therefore empower members not only to intervene but also to initiate the proceeding. The fact that there may be no pre-existing association at hand also justifies permitting any interested person to file a complaint. In any case, courts may simultaneously watch out for frivolous litigation, protect the concerns of all and fully enforce the group rights at issue.

\section{POPUlar ACTIONS}

Several Latin American jurisdictions have embraced the popular action. ${ }^{77}$ The actio popularis, a creature of Roman law, enables citizens to protect societal goods through the courts. U.S. law contains, exceptionally, similar procedures. For instance, a few federal statutes authorize citizen suits, which enable personally affected plaintiffs to assert the public's interest through litigation. ${ }^{78}$ Similarly, qui tam actions empower individuals to challenge conduct that injures society in general, such as the filing of "false claims."79 Latin American litigants, unlike their neighbors north of the border, ${ }^{80}$ normally do not face strict standing requirements when bringing these complaints.

Brazil's Constitution, for instance, allows citizens to sue anyone who damages or misappropriates public property, as well as any

77. See Braz. Const. art. 5(LXXIII); Colom. Const. art. 88; PAN. Const. art. 290; Peru Const. art. 200(5). Curiously, Panama's Constitution establishes a unique "popular action to challenge in court any combination, contract, or action in support of monopolistic practices." PAN. CONST. art. 290.

78. See, e.g., Clean Air Act, 42 U.S.C. $\S 7604$ (2000); Clean Water Act, 33 U.S.C. $\S$ 1365 (2000); Endangered Species Act, 16 U.S.C. $\S 1540(\mathrm{~g})(2000)$; Clayton Antitrust Act, 15 U.S.C. $\S 15$ (a) (2000).

79. See False Claims Act of 1863,31 U.S.C. $\$ \S 3729-3733$ (2000); see also discussion supra note 33.

80. The U.S. Supreme Court has strictly required an "injury-in-fact" in citizen suits, such as under the Endangered Species Act of 1973, 16 U.S.C. $\$ 1536$ (2000). See Lujan v. Defenders of Wildlife, 504 U.S. 555, 572-73 (1992). Nonetheless, the tribunal has found an "adequate basis for [a qui tam] suit ... in the doctrine that the assignee of a claim has standing to assert the injury in fact suffered by the assignor," and concluded "that the United States' injury in fact suffices to confer standing." Vermont Agency of Natural Res. v. United States ex rel. Stevens, 529 U.S. 765, 773-74 (2000). 
public official who defiles "administrative morality, the environment, or historical and cultural goods." $"$ In these lawsuits, petitioners seek to protect the interests of the entire citizenry. They have standing merely by virtue of their citizenship. As in U.S. collective litigation, ${ }^{82}$ the final judgment on the merits binds all other citizens. ${ }^{83}$ In other words, if an individual subsequently files another popular action, she will face dismissal on the basis of the principle of res judicata.

Article 18 of the Popular Actions Act carves out an exception when the court dismisses the suit for lack of proof. ${ }^{84}$ Under these circumstances, it permits any citizen, including the original plaintiff, to sue anew. In the United States, res judicata rules on dismissal operate in representative suits in the same ways as they do in other actions. The relevant precept reads thus: "Unless the dismissal order states otherwise, a dismissal. . .- except one for lack of jurisdiction, improper venue, or failure to join a party under [compulsory joinder]-operates as an adjudication on the merits." 85 If the tribunal rejects the claim for insufficient evidence, it implicitly bars subsequent

81. BRAZ. CONST. art. 5(LXXIII).

82. See Harold J. Kent \& Ethan G. Shenkman, Of Citizens Suits and Citizen Sunstein, 91 MiCH. L. REV. 1793, 1814 n.79 (1993) These authors explain:

Citizen suits could have a res judicata effect under the theory that plaintiffs acting in the capacity of private attorneys general are in privity with other plaintiffs acting in the same capacity. Otherwise, defendants might be subject to an unlimited number of citizen suits for the same violations, at least until the maximum liability for each violation [were] exhausted.

Id. See also Cooper v. Federal Reserve Bank of Richmond, 467 U.S. 867, 874 (1984) ("There is . . . no dispute that under elementary principles of prior adjudication a judgment in a properly entertained class action is binding on class members in any subsequent litigation ... Basic principles of res judicata (merger and bar or claim preclusion) and collateral estoppel (issue preclusion) apply."); United States ex rel. Yankton Sioux Tribe v. Gambler's Supply, 925 F. Supp. 658, 667-68 (D.S.D. 1996). In Gambler's Supply, the district court noted that

[t] ]he res judicata effect of a qui tam action was explained by Mr. Blackstone who stated, 'But if any one hath begun a qui tam or popular action, no other person can pursue it; and the verdict passed upon the defendant in the first suit is a bar to all others, and conclusive even to the king himself.'

Id. (quoting Miami Copper Co. v. State, 17 Ariz. 179, 188 (1915) (quoting Cooley's Blackstone, Vol. 2, pp. 972, 973, 974)).

83. Lei No. 4.717, de 29 de Junho de 1965, art. 18, D.O.U. de 5.7.1965 (Braz.), translated and reprinted in OQUENDO, supra note 30, at 713 ("The judgment shall constitute res judicata, erga omnes ....").

84. Id. ("The judgment shall constitute res judicata, erga omnes, except in cases of dismissal for insufficiency of proof. Whenever this exception applies, any citizen may file another action on the same grounds and introducing new evidence.").

85. FED. R. CIV. P. 41(b). 
litigation, unless it makes an explicit statement to the contrary.

Ultimately, the Brazilian scheme may not operate as restrictively as it seems. If a judge wants to dismiss the suit with prejudice, she must simply specify that the proof actually suffices to ascertain that the petitioner has no case. The main difference between the Brazilian framework and its U.S. counterpart is that the latter presumes that dismissal for insufficiency of evidence precludes re-litigation, while the former does not.

Brazilian plaintiffs in popular actions, unlike U.S. class representatives, raise comprehensive (as opposed to group) claims. As already noted, they need not show a personal injury or an individual stake in the controversy. Nor do they have to establish the adequacy of their representation. They therefore do not have to face attempts by defendants or courts to use these requirements to block legitimate claims. At the same time, they do not have to prove that they will litigate vigorously and responsibly before representing and binding the public at large.

The relevant statute somewhat reduces the danger of anemic or deficient litigation by compelling the participation of the Public Ministry in all suits of this kind. ${ }^{86}$. This body will ordinarily contribute competent and objective plaintiff lawyers to the cause. It possesses considerable advocacy resources and enjoys both financial and administrative autonomy vis-à-vis the government. ${ }^{87}$ Its staff attorneys secure their prestigious, well-paid and life-tenured positions upon a competitive selection process that includes a demanding specialized exam. ${ }^{88}$ They not only prosecute criminal cases and institute public civil actions but also broadly safeguard constitutional rights. ${ }^{89}$ The President appoints one of these prosecutors as "Procurator General" to head the institution for a renewable two-year term and must secure the Senate's consent for the appointment as well as for a subsequent removal. ${ }^{90}$

The Public Ministry might not, however, adequately represent the concerns of the citizenry. It may have its own particular agenda,

86. Lei No. 4.717, de 29 de Junho de 1965, art. 6(4), D.O.U. de 5.7.1965 (Braz.), translated and reprinted in OQUENDO, supra note 30 , at 713.

87. BRAZ. CONST. art. 127(2).

88. See id. arts. $127(2), 128(\mathrm{II})(5)(\mathrm{I})$.

89. See generally id. art. 129.

90. Id. arts. 52(III)(e), 52(XI), 84(XIV), 128(II)(1)-(2). 
or it may defend the interests of some citizens at the expense of others. Consequently, lawmakers should amend-or judges should perhaps interpret - the law to require a determination of adequacy of representation, as in U.S. Federal Rule of Civil Procedure 23(a)(4). This approach would force the complainants and the Procurator General's office to demonstrate at the outset that all related claims will have their day in court.

Brazil's constitutional Article 5(LXXIII) specifically relieves popular action plaintiffs of court costs and, if they lose their case on the merits, of automatic fee shifting. ${ }^{91}$ If they litigate frivolously, they have to pay the defendant's costs under Article 13 of the statute, but not its counsel expenses. ${ }^{92}$ Moreover, if they prevail, they may demand that their opponent pay their attorney's fees under statutory Article $12 .^{93}$ By exempting popular action plaintiffs, but not defendants, from the otherwise universally applicable "English Rule," which compels the losing party to pay the litigating expenses of her prevailing adversary, ${ }^{94}$ Brazilian law seeks to encourage this kind of litigation.

Brazil's Supreme Court imposed key restrictions on this type of suit in Paulo de Oliveira, Filho v. Tribunal Superior de Justiça. ${ }^{95}$ In this high-profile dispute, the Superior Justice Tribunal, second in rank in the federal judicial hierarchy, reinstated the mayor of São Paulo, who had been forced out of office on corruption charges. Paulo de Oliveira, Filho, filed a popular action against the Tribunal for allegedly acting as an accomplice to the mayor's corrupt dealings.

The Brazilian justices first resolved that they did not have "original jurisdiction over popular actions" and suggested that only trial courts did. They then described the kind of conduct that plaintiffs may challenge through these suits: "Popular actions aim exclusively at administrative acts or omissions, irrespective of which insti-

91. Id. art. 5(LXXIII).

92. Lei No. 4.717, de 29 de Junho de 1965, art. 13, D.O.U. de 5.7.1965. (Braz.), translated and reprinted in OQUENDO, supra note 30, at 713.

93. Id. art. 12, translated and reprinted in OQUENDO, supra note 30, at 713.

94. See Hensley v. Eckerhart, 461 U.S. 424, 443 n.2 (1983) (The "'American Rule,' under which the parties bear their own attorney's fees no matter what the outcome of a case," differs from "the 'English Rule,' under which the losing party, whether plaintiff or defendant, pays the winner's fees.").

95. Paulo de Oliveira v. Superior Tribunal de Justiça, S.T.F., Pet. 2018 AgR, Relator: Min. de Mello, 22.8 .2000 (Braz.), translated and reprinted in OQUENDO, supra note 30, at 714-17. 
tution or official it is that illegally encroaches upon public property."96

The Court cautioned that this standard did not automatically exempt the judiciary. "Judges may adopt measures that are administrative in content and that illegally undermine public wealth. Under these circumstances, a popular action may lie insofar as the judicial acts or omissions administratively harm state property." 97 Nonetheless, the justices held that the controversy at bar involved "a quintessentially adjudicative act and therefore [did] not allow for the deployment of a popular action."98 They insisted that review of an adjudicator's judgment had to take place through other avenues. "Substantively judicial determinations open up the following two possibilities. If they are not final, they may be appealed in conformity with the procedural legislation. If they amount to a definite decision on the merits, they may be collaterally attacked or rescinded." 99 Similarly, popular actions may serve to contest lawmakers' administration, but not their legislation. Any challenge of the latter must occur either in the political or electoral sphere or through an unconstitutionality suit. ${ }^{100}$

As an upshot, when popular actions target the state, they will normally focus on governmental agencies. Significantly, Article 5(LXXIII) imposes a state action requirement whenever the complaint seeks to tackle corruption or to protect the environment or historical and cultural goods. ${ }^{101}$ Nonetheless, the same provision admits suits against anyone who encroaches upon public property, including ordinary people. ${ }^{102}$ Of course, the complaint in de Oliveira did not implicate any private defendants.

All in all, popular actions offer considerable advantages over U.S. collective suits. First and foremost, they engage the Public Ministry, an autonomous institution without an equivalent in the North. Secondly, they do not demand proof of individualized harm and, accordingly, do not impose a prerequisite that significantly restricts representative litigation in the United States.

$\begin{aligned} \text { 96. } & I d . \\ 97 . & I d . \\ 98 . & I d . \\ 99 . & I d . \\ \text { 100. } & I d . \\ 101 . & \text { BRAZ. CONST. art. 5(LXXIII). } \\ 102 . & I d .\end{aligned}$


In addition, popular actions specifically improve on.U.S. class suits in ways that bring them closer to qui tam and citizen suits. On the one hand, they facilitate the implementation of societal entitlements because they do not compel complainants to define a determinate class. On the other hand, they enable a successful plaintiff not only to avoid court costs but also to recover litigating expenditures. $^{103}$

Relative to class suits, popular actions present certain disadvantages, too, at least in Brazil, and leave room for improvement. In the first place, petitioners need not confirm their representative competence. In this respect, they resemble their counterparts in U.S. qui tam and citizen suits. Moreover, they may not sue private parties in all instances and thus face constraints unknown to collective litigants in the United States. Finally, complainants in popular actions may confront only a limited subset of broadly injurious acts. While the scope of application is extremely wide-ranging in comparison to that of qui tam and citizen suits, it excludes many significant claims, such as those brought to vindicate consumer rights.

Coincidentally, some Latin American legal systems, such as those of Colombia and Peru, neither insulate private parties from litigation in any way nor restrict the range of actionable violations. ${ }^{104}$ Brazilian law actually follows its Colombian and Peruvian analogues in both respects when regulating its foremost collective suit: the public civil action. ${ }^{105}$ This difference in regulation explains, in part, why trans-individual litigation in Brazil has tended to gravitate towards this procedure. The bulk of the explanation, however, lies in the fact that the Procurator General's office, as well as associations, may initiate the proceeding. In contrast, legal entities, whether governmental or not, may not file a popular action; only individual citizens may. ${ }^{106}$

Although somewhat underutilized in Brazil and not universally available in Latin America, the popular suit constitutes a key process for the realization of the citizenry's rights. It has the poten-

103. Compare Lei No. 4.717, de 29 de Junho de 1965, art. 12, D.O.U. de 5.7.1965. (Braz.), translated and reprinted in OQUENDO, supra note 30, at 713, with False Claims Act, 31 U.S.C. $\S 3730(d)(2)$ (2000); Clean Air Act, 42 U.S.C. $\S 7604$ (d) (2000); Clean Water Act, 33 U.S.C. § 1365(d) (2000); Endangered Species Act, 16 U.S.C. $§ 1540(\mathrm{~g})(4)(2000)$; Clayton Antitrust Act, 15 U.S.C. $§ 15($ a) (2000).

104. See Colom. Const. art. 88; Peru Const. art. 200(5).

105. See discussion in Part V.

106. Summary 365, S.T.F., 13.12.1963 (Braz.). 
tial to make an enormous difference throughout the continent, particularly if it is improved along the lines intimated. U.S. law would, likewise, profit handsomely from either introducing a similar procedure (i.e., a generic citizen's suit) or reforming its class action to incorporate some of the advantageous aspects of the procedural mechanism under consideration. Needless to say, any crossfertilization effort should take into earnest account the legal and cultural background conditions.

\section{Public Civil ACtions}

Latin American state agencies and private associations - such as public ministries and environmental organizations-have traditionally exerted themselves in the public interest largely outside the courtroom. Lately, however, they have turned ever more often to the judiciary in order to advance broad communal and societal ends. ${ }^{107}$ They have frequently sought class-wide remedies by filing public civil actions. These suits, which vary significantly in name and in detail from one country to the next, have generally opened up a previously unimaginable path to the implementation of first-, secondand third-generation rights.

Brazilian law, for instance, allows the Public Ministry, "a permanent institution, essential to the state's judicial function [and charged with defending] the legal order, the democratic system, and all inalienable social and individual interests," 108 to bring public civil actions on behalf of a sizeable group of people. These suits purport "to address moral and pecuniary injuries to (I) the environment; (II) consumers; (III) the urban order; (IV) goods of artistic, aesthetic, historical, tourism, and landscape value; (V) other comprehensive or collective interests; or (VI) the economic order or the popular economy."109 Certain other state entities and private associations may also file the complaint; however, individuals may not. ${ }^{10}$

Brazil's Congress enacted the relevant statute in $1985 .^{111}$ It

107. See generally MARGARET KECK \& KATHRYN SIKKINK, ACTIVISTS BEYOND BORDERS: ADVOCACY NETWORKS IN INTERNATIONAL POLITICS (1998).

108. BRAZ. CONST. art. 127.

109. Lei No. 7.347, de 24 de Julho de 1985, art. 1, D.O.U. de 25.7.1985. (Braz.).

110. Id. art. 5.

111. Id. 
drew on existing local institutions, such as the popular action, and foreign concepts, especially the U.S. class action. ${ }^{112}$ The 1988 Constitution endorses this procedure in defining the Procurator General office's functions and duties. ${ }^{13}$

Not surprisingly, the Public Ministry has led the way in public civil litigation. It has thus contributed enormously to the protection of group and comprehensive entitlements. Nonetheless, Brazilian non-governmental organizations have played an increasingly prominent role. Though modest relative to their first-world counterparts, they have grown in resources and experience over the last twenty years and have, accordingly, enhanced their effectiveness in promoting this kind of suit.

In U.S. class actions (as opposed to qui tam or citizen suits) the judge has to make a finding of adequate representation prior to certification. ${ }^{114}$ The Brazilian public civil action law, like that on popular actions, calls for no such determination. ${ }^{115}$ Some scholars have persuasively argued that the court should nonetheless probe the adequacy of the representation. ${ }^{116}$

Of course, Article 5(1) of the statute requires the Public Ministry to intervene whenever it does not itself file the claim and to represent the public interest. ${ }^{117}$ As noted in Part IV, such a provision generally guarantees the presence of competent plaintiff lawyers in the proceedings, but not necessarily a steadfast defense of the common good as perceived by the people affected. Moreover, the Procurator General's office can hardly provide all of the beneficiaries a satisfactory representation when they have conflicting concerns, preferences or expectations.

Interestingly, Article 13 of the Public Civil Actions Act calls for a fund into which defeated defendants must pay damages. It demands that the Public Ministry and community delegates take part in the administration of the monies. This arrangement reflects the aspi-

112. Pedro Leza, TeORIa Geral da AÇão CIVIL Pública 161-62 (2003).

113. BRAZ. CONST. art. 129(III).

114. FED. R. CIV. P. 23(a)(4).

115. See Lei No. 7.347, de 24 de Julho de 1985, art. 1, D.O.U. de 25.7.1985. (Braz.).

116. Antônio Gidi, A Representação Adequada nas Ações Coletivas Brasileiras. Uma Proposta, 108 REV. DE PROCESSO 61 (2002); Ada Pellegrini Grinover, Ações coletivas IberoAmericanas: novas questões sobre a legitimação e a coisa julgada, 98 REV. FORENSE 4, 5 (2002); PEDRo LeZA, TEORIA GERAL DA AÇÃo CIVIL PÚBLICA 195-96 (2003).

117. Lei No. 7.347, de 24 de Julho de 1985, art. 5(1), D.O.U. de 25.7.1985. (Braz.). 
ration that compensation in these suits accrue not to individual plaintiffs as a windfall, but rather to the collectivity as a whole.

Under Article 1, the remedy may include moral damages, which roughly cover pain and suffering, but sometimes also have a punitive component. In public civil actions, any moral indemnification also goes to the fund required by Article 13. In the United States, qui tam judgments divide up treble damages between the government and the relator, while the rare citizen suits that provide for monetary compensation sometimes allow the plaintiff to recover "threefold" compensation for her injuries. ${ }^{118}$ Of course, in U.S. class actions, the court must ensure not only that the remedy is just in regards to all class members but also that any settlement is "fair, reasonable, and adequate."119 At any rate, after the distribution takes place, the beneficiaries spend their part of the award as they see fit.

Res judicata rules under Article 16 of the Public Civil Actions Act reproduce those applicable to popular actions almost exactly. "The judgment" in these actions, accordingly, "shall [generally] constitute res judicata, erga omnes." 120 As a result, any one of the beneficiaries may demand that the defendant comply with a decision that favors all of them and may start an execution proceeding in case of noncompliance. Article 16 differs from its homologue in the Popular Actions Act merely to the extent that it restricts the preclusive effect to "the jurisdictional limits of the issuing court." Accordingly, if a trial court in Bahia rules against a company for discriminating against Afro-Brazilians, the judgment would not bind the defendant elsewhere. Plaintiffs in the state of Minas Gerais would have to file a new complaint in order to stop the enterprise from engaging in the same practices against them.

Furthermore, Article 21 makes the relevant provisions of Title III of the Consumer Code applicable to all public civil actions. As a result, one must interpret the public civil actions statute in conjunc-

118. Compare 31 U.S.C. $\S \S 3729(a)(2), 3730(d)(2)(2000)$ (The violator "is liable to the ... Government for a civil penalty ... plus 3 times the amount of damages [that] the Government sustains because of the" false claim, while "the person bringing the action... shall receive an amount [that] shall be not less than 25 percent and not more than 30 percent of the proceeds of the action ....") with 15 U.S.C. $\$ 15$ (a) (2000) (Any "person ... injured . . . by reason of anything forbidden in the antitrust laws may ... recover threefold the damages by him sustained.").

119. FED. R. CIV. P. 23(e)(2).

120. Lei No. 7.347, de 24 de Julho de 1985, art. 16, D.O.U. de 25.7.1985. (Braz.). 
tion with that Title. The latter, in its Article 81, promotes the vindication of the following catalogue of interests:

(I) comprehensive interests or rights, which are transindividual, as well as indivisible, and pertain to an indeterminate group of people linked by common issues of fact;

(II) collective interests or rights, which are transindividual, as well as indivisible, and pertain to a group, category, or class of people linked to each other or to the opposing party by virtue of a legal relationship;

(III) homogenous individual interests or rights, which stem from a common origin. ${ }^{121}$

This precept, therefore, introduces a complex and abstract taxonomy of group rights. The categories are best illustrated through a concrete example. For instance, a case in which a prison neglects security regulations may give rise to all three kinds of claims.

First, the surrounding neighborhood may assert a comprehensive right to a safe residential environment. The group is defined in terms of the fact that its members live close to the correctional facility. It is basically indeterminate not only because no one knows how far the safety risk will spread, but also because people may move into or out of the area. The right at issue transcends the individual neighbors and cannot be apportioned among them.

Second, the inmates may seek to vindicate a shared right to nonviolent incarceration conditions. They constitute a collectivity by virtue of having a joint legal relationship with the defendant, which has specific juridical obligations towards them as a group. The right at stake transcends the individuals and is not divisible.

Third, homeowners may claim a homogenous individual right to maintain the value of their property. They converge on a set of similar factual and legal circumstances. Their respective rights stem from a common source, viz., homeownership in the vicinity, but are relatively distinguishable from each other.

Of course, these simple illustrations give rise to further uncertainties about the scope of the various classifications. They also raise

121. Código de Proteçao e Defesa do Consumidor [C.D.C.] tit. III(I), art. 81 (Braz.). 
questions about the purpose of the categorization. In fact, the specific categories are somewhat arbitrary, almost as much as those established by Rule 23(b) for class actions in the United States. Both systems would operate more coherently if they generically embraced litigation to protect comprehensive or group entitlements, established a series of common prerequisites for all such suits and empowered trial judges to impose additional strictures on a case-by-case basis.

In Ministério Público do Estado de São Paulo v. Associação Notre Dame de Educação e Cultura, the Brazilian Supreme Court not only struggled considerably with these taxonomical issues, but also generally defined the contours of this procedural institution. "122 "The São Paulo Public Ministry ... filed a public civil action [seeking] a preliminary injunction against respondent, Notre Dame Association for Education and Culture, a school in São Vicente, São Paulo," for raising tuition beyond the "limits established by the State Education Council."123 The high tribunal unanimously agreed with the plaintiff on the merits: "Respondent undoubtedly violated the law when it authorized the tuition hike." 24 The justices further rejected "the contention that the Public Ministry [lacked] standing to defend the interests of the collectivity." 125 "In this concrete case," the Court responded, "the Ministry clearly [had] standing to bring a public civil action in order to protect collective interests in such an extremely delicate and socially significant terrain, which the state must police with utmost care."126

In his concurrence, Justice Celso de Mello agreed "that the Public Ministry [had] standing to file public civil actions to challenge the increase in monthly school fees." 27 He declared further:

The Brazilian legal system appreciates the singularity and importance of certain social values and calls on the state to safeguard them. Accordingly, it has tended, along with its counterparts elsewhere, to collectivize procedural instruments. In particular, it has

122. Ministério Público do Estado de São Paulo v. Associação Notre Dame de Educação e Cultura, S.T.F., RE-163231, Relator: Min. Corrêa, 26.2.1997 (Braz.), translated and reprinted in OQUENDO, supra note 30, at 751-60.

123. Id. (Opinion by Corrêa, J.) $\$ 1$.

124. Id. (Opinion by Corrêa, J.) ๆ 22.

125. Id. $\$ 32$.

126. Id. \31.

127. Id. (Opinion by de Mello, J.). 
created an agile means for an effective protection in court of meta-individual interests. ${ }^{128}$

From this standpoint, de Mello concluded that the Ministry "may certainly file a complaint to defend the collective interests of private school parents and students as well as to impede an arbitrary increase in tuition." 129

Article 84 of Brazil's Consumer Code actually grants courts broad injunctive power in this kind of action. They may deny plaintiffs an injunction only if compliance is impossible. ${ }^{130}$ U.S. law treats this matter radically differently. Federal courts in the United States must refuse a request for injunctive relief whenever damages would sufficiently compensate the complainants. ${ }^{131}$ The Brazilian conception reveals a civil law bias in favor of specific performance. $^{132}$ It demands considerable engagement on the part of the judiciary, which must ordinarily issue an injunction in these cases as well as guarantee compliance.

Article 103, in turn, adds a complex set of res judicata rules that significantly alter the parameters defined in the Public Civil Actions Act. ${ }^{133}$ Specifically, a judgment against a claim based on com-

128. Id.

129. Id.

130. Lei No. 8.078, de 11 de Setembro de 1990, art. 84, D.O.U. de 12.9.1990. (Braz.).

131. The U.S. Supreme Court "has stated that " $[t]$ he basis of injunctive relief in the federal courts has always been irreparable harm and inadequacy of legal remedies." Sampson v. Murray, 415 U.S. 61, 88 (1974) (quoting Beacon Theatres, Inc. v. Westover, 359 U.S. 500, 506-07 (1959)). When damages suffice, plaintiffs have an adequate remedy in law.

132. "The civil law system ... [has] by and large proceeded on the premise that specific redress should be ordered whenever possible ...." E. Allan Farnsworth, Legal Remedies for Breach of Contract, 70 ColuM. L. REV. 1145, 1150-51 (1970). See also E. Allan Farnsworth, Damages and Specific Relief, 27 AM. J. CoMP. L. 247, 249 (1979) (The "proposed preference of Civil law systems" is "for specific relief on doctrinal grounds."). But cf. ARTHUR T. VON MEHREN \& JAMES R. GORDLEY, THE Civil LAW SYSTEM 1123 (2d ed. 1977) (Despite "the German preference for specific relief over other remedies," the French system evinces "difficulties with specific relief," which "may rest in some measure on French society's reluctance ... to put severe pressure on contumacious defendants."). Article 947 of the Brazilian Civil Code seems to make specific performance the preferred form of relief. It declares that debtors may advance the monetary value of the obligation only if they are unable to perform. Código Civil [C.C.] art. 947 (Braz.). In contrast, Articles 247 and 249 appear to express a preference for damages as a remedy. They establish that the debtor must pay the creditor either to hire someone to carry out the obligation or to provide compensation for an unfulfilled duty. C.C. arts. 247, 249 (Braz.). Read together, these three provisions suggest that if the duty is transferable, the debtor must reimburse the creditor for the expense of hiring a substitute, but that if the duty is not transferable, the debtor must, if at all possible, perform or, otherwise, pay damages.

133. Compare Lei No. 7.347, de 24 de Julho de 1985, art. 16, D.O.U. de 25.7.1985. 
prehensive or collective entitlements does not "impair the individual interests and rights" of the people represented. ${ }^{134}$ As a result, any such person may subsequently file a new complaint on her own behalf. Furthermore, if the final decision refuses to recognize claimed homogenous individual rights, "any concerned person who did not intervene in the original proceeding may file an individual indemnification action." 135

The judgments in these actions, consequently, have extremely asymmetrical res judicata effects. When the plaintiff seeks to enforce comprehensive or collective entitlements, the purported beneficiaries profit from a victory, but do not have to endure the consequences of a defeat. Since complaints for the enforcement of homogenous individual rights typically seek damages, the people concerned usually also benefit from a favorable determination, but are not bound by an unfavorable outcome. Hence, all of these individuals have an incentive not to seek intervention in the original action, so as to take a second bite at the apple in case of defeat.

In general, this asymmetry operates unfairly vis-à-vis the defendant and leads to inefficiency, viz., to repetitive litigation. In light of the absence of an adequacy of representation requirement, however, the individuals affected could legitimately object to a symmetrical approach. In other words, they could justifiably remonstrate against the extinction of their entitlements upon a process that did not properly consider their interests. Therefore, a move towards symmetry in the preclusion regime should go hand in hand with a shift towards demanding that complainants demonstrate their ability to represent everyone fairly.

Peru and Uruguay have already incorporated this kind of "comprehensive interest" action into their legal order; ${ }^{136}$ other Iberian American nations are presently considering following suit. ${ }^{137}$ In both

(Braz.) with Lei No. 8.078, de 11 de Setembro de 1990, art. 103, D.O.U. de 12.9.1990. (Braz.).

134. Lei No. 8.078, de 11 de Setembro de 1990, art. 103(1), D.O.U. de 12.9.1990. (Braz.).

135. Id. art. 103(2).

136. See Resolución Ministerial No. 10-93-JUS, art. 82, 8 Jan. 1993, Texto Unico Ordenado del Código Prosecal Civil (Peru); Ley No. 15.982, art. 42, 18 Oct. 1988, Código General del Proceso (Uru.).

137. The proposed Constitution in Bolivia, for instance, creates a popular action through which individuals, groups, the Public Ministry, and the People's Defender may defend rights and interests "related to public patrimony, space, security, or health or to environment, as 
the Peruvian and the Uruguayan legislative schemes, however, the final collective decision does bar posterior individual complaints. ${ }^{138}$ In any case, Peru's statute does adhere to the Brazilian model to the extent that it invites petitions by the "Public Ministry, as well as [by] nonprofit associations or institutions that have standing by statute or by virtue of a duly grounded determination by the judge." "139 Uruguay's law, in turn, additionally entitles "any interested individual" to sue. ${ }^{140}$ As noted in Part III, the Argentine Constitution also authorizes "individuals affected" to file these suits. ${ }^{141}$

The state and existing organizations may, of course, fail to litigate in a fully representative manner. In view of this reality, individual participation in the judicial realization of comprehensive rights is fundamental. In response, Brazil, as well as Peru, could either permit individuals to bring public civil actions or allow popular suits to advance all kinds of comprehensive entitlements and encourage any affected person to seek a collective writ of security.

The public civil action will undoubtedly continue to diverge from the Brazilian paradigm as it expands to other countries in the region. Nonetheless, it has the potential to follow in the twenty-first century the course that the writ of protection underwent in the twentieth century and, accordingly, become a universally available procedure throughout Iberian America. It might then have as colossal an impact all over the region, as it has had in Brazil. Only time will tell.

\section{RESTRUCTURING U.S. REPRESENTATIVE LITIGATION}

As suggested in the introduction, the U.S. legal world could

well as other similar entitlements ...." Nueva Constitución Política del Estado de Bolivia [Proposed Constitution] arts. $136 \& 137$ (2007) (Bolivia). The charter thus essentially establishes a public civil action that does not preclude individual initiation. In Ecuador, the text submitted by the Constitutional Assembly similarly provides for a collective writ of protection for "communitarian interests," as well as for "solidarity-based, collective, or comprehensive rights." Proyecto de Constitución de la República del Ecuador [Proposed Constitution] art. 113(4) (2007) (Ecuador).

138. See Resolución Ministerial No. 10-93-JUS, art. 82, 8 Jan. 1993, Texto Unico Ordenado del Código Prosecal Civil (Peru); Ley No. 15.982, art. 220, 18 Oct. 1988, Código General del Proceso (Uru.).

139. Resolución Ministerial No. 10-93-JUS, art. 82, 8 Jan. 1993, Texto Unico Ordenado del Código Prosecal Civil (Peru).

140. Ley No. 15.982, art. 42, 18 Oct. 1988, Código General del Proceso (Uru.).

141. ARG. Const. art 43. 
find inspiration in Latin America to improve its own approach to collective litigation. In the first place, it could create a popular suit for the protection of comprehensive entitlements. United States lawmakers could, secondly, institute an independent state body, along the lines of the Public Ministry, with power to file both communal and societal complaints. The Judicial Conference's civil advisory committee could, thirdly, modify Rule 23 of the Federal Rules of Civil Procedure to grant standing to organizations, as well as individuals, to file class actions. It could, finally, embrace a single, straightforward 23(b) classification.

The U.S. government could take a page from its Latin American counterparts and entitle private parties to vindicate any kind of comprehensive right. It could achieve this end either by amendment of the procedural rules or by statutory enactment. At present, litigants may sue on behalf of society as whole only if they qualify to initiate a qui tam or citizen suit under one of the few statutes available for that purpose. Of course, they may also attempt to masquerade as a subgroup and file a class action. Nonetheless, such a strategy normally forces them to scale back or abandon their macrocollective aim, inasmuch as they must restrict themselves to defending micro-collective interests.

The proposed mechanism could, conceivably, incorporate the standing requirements set forth by the federal Supreme Court for citizen suits. ${ }^{142}$ Alternatively, and preferably, it could operate as a qui tam action and embrace the premise that the state assigns its claim to the plaintiff. ${ }^{143}$ In this context, the justices have embraced "the doctrine that the assignee of a claim has standing to assert the injury in fact suffered by the assignor" and have concluded "that the United

142. See Lujan v. Defenders of Wildlife, 504 U.S. 555, 560-61 (1992). The Court stated:

Over the years, our cases have established that the irreducible constitutional minimum of standing contains three elements. First, the plaintiff must have suffered an "injury in fact" - an invasion of a legally protected interest which is (a) concrete and particularized; and (b) "actual or imminent, not 'conjectural' or "hypothetical." Second, there must be a causal connection between the injury and the conduct complained of ... . Third, it must be "likely" as opposed to merely "speculative," that the injury will be "redressed by a favorable decision."

Id. (internal citations omitted).

143. See, e.g., 31 U.S.C. $\$ 3730(b)(1)$ (2000) ("A person may bring a civil action for a violation of section 3729 for the person and for the United States Government. The action shall be brought in the name of the Government."). 
States' injury in fact suffices to confer standing." 144

The procedure in question would not, in itself, threaten the legislature's prerogative to protect the common weal. It could incorporate the prerequisite that tribunals generally exercise substantial prudence and that they specifically dismiss any societal litigation that might undermine legitimate legislative action. Judicial enforcement would then take place only under exceptional circumstances. While litigants would not have to wait for a law authorizing them to proceed, they would face a rather strict standard in court.

The United States could, additionally, learn from its southern neighbors about the benefits of disposing of an autonomous public entity for the implementation of meta-individual rights. It could come to appreciate how such an institution might avoid the political pressure that the Attorney General and administrative agencies confront when attempting to address controversial claims. The Congress could, consequently, establish an equivalent to the Procurator General's Office, carefully minding local idiosyncrasies. It could reduce redundancy and inefficiency by demanding that that the body's staff attorneys collaborate closely with the Justice Department, as well as with relevant administrative agencies.

Furthermore, U.S. rule-making authorities could allow a nongovernmental association to pursue class remedies directly. Under the current regime, it must recruit part of its membership to serve as representatives. It thus may not itself play the role of the real party in interest, must find substitutes and amend its pleadings if the original plaintiffs drop out, and risks a shift in focus from the collective to the individual. The recognition of associational standing would remove these difficulties.

U.S. lawyers and scholars could draw lessons not only from the successes, but also from the failings of the representative litigation model south of the border. They could, for example, transition from noticing the previously described unwieldiness of the three categories of the Brazilian public civil action to realizing the arbitrary nature of the categorization of class suits in the United States. Thereupon, they could conceive significant improvements.

The three subsections of Rule 23(b) of the U.S. Federal Rules

144. Vermont Agency of Natural Res. v. United States ex rel. Stevens, 529 U.S. 765, 773-74 (2000). 
of Civil Procedure define a triad of class action types: viz., cohesion, injunction and commonality suits. ${ }^{145}$ They jointly set forth a precondition for a class certification, inasmuch as a plaintiff seeking communal relief must fit her claim within one of them. In addition, they entail different entitlements and duties. For instance, representatives in cohesion or injunctive suits under Rule 23(b)(1) or 23(b)(2), in contrast to their counterparts in commonality actions under 23(b)(3), need not send individual notification to class members. ${ }^{146}$

All in all, the drafters formulated the third subdivision as a residual category-almost a consolation prize-for claimants unable to exercise either of the two other options. However, they never fully justified this arrangement. While the committee based stricter notice requirements on the strength of "the interests of the individuals in pursuing their own litigations," 23(b)(3) suits do not differ significantly from the other two types of class action in this respect. ${ }^{147}$ Furthermore, the three classifications have unclear bounds and point to similarly controversial subcategories. In fact, they have given rise to considerable confusion and limitless litigation. ${ }^{148}$

The regulation of class suits in the United States, like that of public civil actions in Brazil, would profit handsomely from eliminating the cumbersome existing categorization. A single group-suit category would do. The trial judge could then make determinations on a case-by-case basis with respect to the appropriateness of litigating collectively, the manageability of the action, the notification and opt-out rights of class members and so forth.

As previously noted, the U.S. legal order has recently tended to restrict rather than expand representative suits, mostly in order to contain excessive and frivolous litigation. ${ }^{149}$ In any case, the recommended innovations, which would help advance the crucial ends of meta-individual suits, might not lead to an increase in the total number of proceedings. Moreover, enhanced judicial supervisory and punitive powers could help keep abuse in check.

145. See FED. R. Civ. P. 23(b).

146. See Eisen v. Carlisle \& Jacquelin, 417 U.S. 156 (1974) (requiring 23(b)(3) class action representatives to notify all members individually and to pay the entire cost of notification).

147. FED. R. CIV. P. 23(c)(2) advisory committee's note on 1966 amendments.

148. See, e.g., Ortiz v. Fibreboard, 527 U.S. 815 (1999); Amchem v. Windsor, 521 U.S. 591 (1997).

149. See supra notes $16-17$ and accompanying text. 
Needless to say, extreme hostility to public law adjudication might impede a reasonable discussion of these issues. Under such circumstances, advocates of change would have no choice but to formulate their arguments as persuasively as possible and to show immense patience. They would have to alter attitudes throughout the nation not just about collective entitlements, but about law, lato sensu.

Obviously, these proposals call for further analysis. How exactly would they work in practice? To what extent do they genuinely respect the United States' legal peculiarity and difference vis-à-vis Iberian America? Could they realistically command sufficient support for their eventual adoption? This section has merely set the debate in motion.

VII. WRAP-UP

Latin America has started a true revolution in the area of collective rights: moving beyond the paradigm of group entitlements to that of comprehensive entitlements. It took a first, almost rhetorical step by granting constitutional stature to a new set of substantive rights. It has since consolidated this shift by creating procedural mechanisms to breathe life into these guaranties.

This article has considered how Iberian American nationsmost conspicuously Brazil-have taken the idea of trans-individual rights and processes, largely from the United States, and radically transformed it. Various jurisdictions in the region have found inspiration in the U.S. class action to create locally flavored suits for the implementation of group entitlements. They have, additionally, instituted special procedures for the vindication of comprehensive guarantees.

Latin American legal systems have frequently authorized private entities and individuals to defend, as litigants, micro-collective, as well as macro-collective, rights. They have also granted this power to autonomous state bodies, such as the Procurator General's Office, which have performed aggressively on this front. This article has proposed continuing and expanding these efforts.

Following the introduction, Part II explored the notion of representative litigation and contrasted U.S., European and Iberian 
American perspectives on the matter. Part III examined the collective writ of protection as a device for the realization of communal rights and recommended that, beyond organizations, individuals have the right to sue. Part IV analyzed the popular action as a mechanism through which individuals may implement certain societal rights. It suggested expanding the scope of the suit to incorporate all such entitlements and allowing associations to initiate litigation. Further, Part $\mathrm{V}$ considered the use of public civil actions by the Procurator General to enforce group and comprehensive entitlements. It suggested simplifying the suit by defining the protected guaranties more flexibly and by widening the preclusion consequences. Parts III, IV and V all espoused imposing an adequacy-of-representation requirement. Finally, Part VI advocated modifying the U.S. legal system, by carefully drawing on these three procedural actions.

Micro- and macro-collective litigation underscores the interconnection between legal substance and procedure. Even a classically negative and first-generation right, such as free speech, profoundly transforms itself when its enforcement may take place collectively. It offers new procedural possibilities and, most significantly, it moves beyond protecting personal expressions of ideas to facilitating group and even societal self-determination. A metaindividual suit in this area often entails much more than an aggregation of numerous ordinary actions. It frequently enables people not merely to speak their minds, but additionally to coalesce into a community or a movement. For instance, the right of state employees to use their native tongue in informal settings transmutes intensely when asserted by a collectivity-such as the Aymaras in Bolivia or Latino/as in the United States-instead of an isolated individual. The interface between substantive and procedural law in this realm, as well as in others, certainly deserves additional attention and study.

Collective suits, like protection and unconstitutionality actions, have had a peculiar history and have played a key role in the defense of fundamental guaranties in Latin America. Nonetheless, they surfaced more recently than these two other procedural devices, are still basically under construction, and, therefore, have yet to take a mature, or relatively stable, form. Over the next several years, one will have a clearer sense of how this kind of litigation will finally shape up and affect the rights ethos across the continent.

These representative actions have found broad appeal in Ibe- 
rian America partly as a way to make up for people's longstanding lack of access to justice and to address large-scale violations of rights. They generally enable tribunals to process mass injuries efficiently and to face up directly to vital public values. Latin America should continue to upgrade these causes of action, minding both experiences abroad and local conditions. The rest of the world should, in turn, take notice of the remarkable regional achievements on this front.

U.S. law has much to learn from the investigated accomplishments. It could, first, empower any concerned individual or organization to enforce societal entitlements and, second, establish an independent entity, similar to the public ministry, with the authority to set collective suits in motion. The framers of the Federal Rules of Civil Procedure could, third, concede standing to associations, as well as individuals, to file class actions. They could, finally, re-draft and improve Rule 23 by formulating a single, clear-cut category under section 23(b).

This piece has painted a predominantly positive picture and insisted upon its reality, salience and underestimation. It has taken a page from Paul Gauguin by maintaining paradise in sight and refusing to dwell on the occasionally hellish conditions encountered on site. ${ }^{150}$ Unlike Gauguin, however, this work has recognized imperfections and impediments from the outset and has approached its subject overall not externally, as sublime exotica, but rather internally, from the perspective of the players involved. From such an outlook, it has consistently pointed to existing institutional flaws and possible improvements and will now briefly reflect upon more structural and rather entrenched challenges. It will thus invite further future reflection.

The successes under examination have periodically taken place even against an adverse backdrop of a weak adherence to the rule of law. In fact, the extent to which people and institutions in Latin America honor this notion varies enormously among and within the various countries in the region and has noticeably increased in the last two decades. ${ }^{151}$ Nonetheless, the problem persists

150. See generally PAUl GAUGUIN, AVANT ET APRES, AVEC LES VINGT-SEPT DESSINS DU MANUSCRIT ORIGINAL (1923).

151. Rogelio Pérez Perdomo similarly qualifies the extent of the mismatch between legal practices and principles. Rogelio Pérez Perdomo, Notas para una historia social del de- 
and intermittently threatens, inter alia, the collective realization of rights.

The previously mentioned victories could prove to be short lived within such an environment. Beyond adopting new measures or punishing violators more severely, Latin American countries must succeed in the unlikely task of changing the underlying culture. They must effectively enhance the legitimacy of legal norms across the board by renewing their commitment to democracy, as well as to other ideals, such as the rule of law itself, personal freedom and (above all) solidarity.

Of course, even if Latin America takes these enormous and improbable steps towards the institutionalization of the principle of legality and ensures the fulfillment of group and comprehensive entitlements, it will not automatically attain social justice. The implementation of rights plays a central, but only limited-and occasionally counterproductive-part in the fight against societal injustice. This battle demands a broader and deeper engagement, within and without the state, against inequity and marginalization. Legal actors throughout the region will need to take other steps-in addition to (and sometimes in substitution of) the pursuit of trans-individual entitlements - in order to attain emancipation for all. 